\title{
PENGARUH PEMBENTUKAN HOLDING COMPANY BUMN PADA SEKTOR KEUANGAN TERHADAP PEMBERDAYAAN USAHA MIKRO, KECIL, DAN MENENGAH
}

\author{
Fa'iq Muzhaffar Syach \\ Program Studi IImu Hukum, Fakultas Hukum, Universitas Islam Indonesia \\ Yogyakarta
}

\begin{abstract}
Abstrak
Badan Usaha Milik Negara ("BUMN") di Indonesia merupakan salah satu penopang perekonomian negara. Penting bagi pemerintah untuk selalu mengoptimalkan kinerja BUMN di Indonesia untuk meningkatkan perekonomian negara, salah satunya melalui restrukturisasi BUMN dengan membentuk holding company. Di penghujung tahun 2020 , pemerintah melalui Menteri BUMN menunjukkan antusiasnya dengan memaparkan rencana holding BUMN di bidang keuangan antara PT Bank Rakyat Indonesia Tbk, PT Pegadaian (Persero), dan PT Permodalan Nasional Madani (Persero). Tujuan utama dari rencana holding company adalah untuk membangun ekosistem bagi bisnis ultra-mikro sehingga layanan keuangan formal dapat tercapai. Mengingat pentingnya keberadaan UMK-M di Indonesia untuk menunjang perekonomian negara, maka perlu dikaji secara mendalam pengaruh rencana perusahaan holding company BUMN di bidang keuangan terhadap pemberdayaan UMK-M.
\end{abstract}

Kata Kunci: Holding Company, BUMN, UMK-M

\begin{abstract}
Badan Usaha Milik Negara ("BUMN") in Indonesia are one of the pillars of the country's economic. It's important for the government to always optimize the performance of BUMN in Indonesia to improving the country's economic, one of which is through restructuring of BUMN by forming aholding company. At the end of 2020, the government, through the Minister of BUMN, showed it's enthusiasm by presenting the BUMNholding company plan in the financial sector between PT Bank Rakyat Indonesia Tbk, PT Pegadaian (Persero), and PT Permodalan Nasional Madani (Persero). The main objective of theholding company plan is to build an ecosystem for ultra-micro businesses so that formal financial services can be reached. Given the importance the existence of UMK-M in Indonesia to supporting the country's economic, it's necessary to study in depth for the effect of BUMNholding company plan in the financial sector on the empowerment of UMK-M.
\end{abstract}

Keywords: Holding Company, BUMN, UMK-M

\section{PENDAHULUAN}

Badan Usaha Milik Negara ("BUMN") merupakan suatu entitas yang dinilai menjadi salah satu pilar ekonomi negara. Pengaruh BUMN terhadap ekonomi negara dapat dibuktikan dengan meningkatnya pendapatan negara yang berasal dari BUMN pada akhir Maret 2020 sebesar Rp.375,9 trilliun atau bertumbuh $7,7 \%$ dari tahun yang lalu. ${ }^{1}$ BUMN merupakan suatu badan usaha yang memiliki karakteristik istimewa dibandingkan badan usaha lainnya, yaitu dianggap sebagai badan usaha berbaju pemerintah namun memiliki fleksibilitas dan cakupan kegiatan seperti perusahaan swasta. Hal tersebut merupakan suatu kelebihan tersendiri, negara hadir di dalamnya sebagai pemegang saham mayoritas dalam kegiatan ekonomi dengan tujuan negara dapat melakukan intervensi terhadap BUMN untuk mengurangi kegagalan pasar, kekakuan harga, dan menyelaraskan kegiatan ekonomi dengan regulasi hukum yang berlaku. Berdasarkan penjelasan tersebut, betapa pentingnya pemerintah untuk mengoptimalkan kinerja $B U M N$ di Indonesia dalam meningkatkan 
ekonomi negara.

Terdapat salah satu upaya untuk meningkatkan kinerja BUMN yaitu restrukturisasi melalui pembentukan holding company. Menurut Munir Fuady, holding company adalah suatu perusahaan yang bertujuan untuk memiliki saham dalam satu atau lebih perusahaan lain atau mengatur satu atau lebih perusahaan lain tersebut. ${ }^{2}$ Adapun berdasarkan Undang-Undang Nomor 8 Tahun 1995 tentang Pasar Modal ("UU PM") mengartikan holding company sebagai suatu hubungan afiliasi. Berdasarkan Pasal 1 butir 1 UU PM, hubungan yang dianggap sebagai afiliasi adalah hubungan antara dua perusahaan di mana terdapat satu atau lebih anggota direksi atau dewan komisaris yang sama, hubungan antara perusahaan dan suatu pihak, baik langsung maupun tidak langsung mengendalikan atau dikendalikan oleh perusahaan tersebut, hubungan antara dua perusahaan yang dikendalikan baik langsung maupun tidak langsung oleh pihak yang sama, serta hubungan antara perusahaan dan pemegang saham utama. Di Indonesia telah dilakukan beberapa holding company BUMN, seperti pada tahun 2012 dari PT Semen Gresik Tbk menjadi PT Semen Indonesia Tbk, pada tahun 2012 dari PT Pupuk Sriwidjaja menjadi PT Pupuk Indonesia holding company, dan pada tahun 2014 terbentuk holding company PT Perkebunan Nusantara III yang membawahi 14 perseroan terbatas. ${ }^{3}$ Semangat pemerintah dalam restrukturisasi BUMN bahkan tidak berhenti sampai saat ini. Pada akhir tahun 2020, Menteri BUMN RI, Erick Thohir menyatakan rencana holding company terkait pembiayaan dan pemberdayaan ultramikro serta UMK-M yang terdiri dari tiga perusahaan BUMN yakni PT Bank Rakyat Indonesia Tbk (“BRI”), PT Pegadaian ("Pegadaian"), dan PT Permodalan Nasional Madani (PT PNM), yang mana BRI sebagai perusahaan induknya. ${ }^{4}$

Mengingat ketiga BUMN tersebut merupakan badan usaha yang bergerak pada sektor jasa keuangan, pelaksanaan holding company dinilai tepat dalam rangka membantu membangkitkan kembali ekonomi negara yang telah terdampak selama pandemi Covid-19 serta sejalan dengan dukungan pemerintah terhadap Usaha Mikro, Kecil dan Menengah (“UMK-M"). Tujuan utama dari holding company ini adalah untuk membangun ekosistem agar semakin banyak pelaku usaha ultra mikro terjangkau layanan keuangan formal. ${ }^{5}$ Tidak dapat dipungkiri, bahwa salah satu upaya dalam meningkatkan dan mengembangkan UMK-M khususnya dalam mendukung perekonomian nasional yaitu dengan cara mendorong pemberian kredit modal usaha kepada UMK-M. Pentingnya keberadaan UMK-M dalam mendukung perekonomian nasional berdasarkan data dapat dilihat pada tahun 2015, UMK-M telah berkontribusi sebanyak 57,60\% Produk Domestik Bruti ("PDB") dan memiliki tingkat penyerapan tenaga kerja sekitar 97\% dari seluruh tenaga kerja nasional. Selain itu, ketika krisis ekonomi periode 1997-1998, berdasarkan data Badan Pusat Statistik ("BPS"), UMK-M pada saat krisis ekonomi tidak berkurang, justru bertambah bahkan dapat menyerap sebanyak 85 juta hingga 107 juta pekerja hingga tahun $2012 .{ }^{6}$

Namun, berdasarkan beberapa uraian di atas, belum cukup menjadi landasan bahwa para pelaku UMK-M di Indonesia mendapatkan kemudahan fasilitas dalam hal permodalan usaha ke lembagalembaga pemberi kredit baik perbankan maupun non perbankan. Sejauh ini, berdasarkan data dari BPS, telah mengidentifikasikan permasalahan umum yang dihadapi UMK-M antara lain kurangnya permodalan, kesulitan pemasaran, persaingan usaha yang ketat, kesulitan bahan baku, kurangnya teknis produksi dan keahlian, keterampilan manajemen yang kurang dan iklim usaha yang kurang kondusif. ${ }^{7}$

Maka dari itu, dalam rangka mengoptimalkan perekonomian nasional melalui pemberdayaan UMK-M di Indonesia, penting untuk mengkaji secara komprehensif terhadap rencana holding company BUMN pada sektor keuangan guna mendukung 
perkembangan UMK-M. Perlu dilakukannya pembahasan melalui beberapa poin permasalahan antara lain aspek hukum restrukturisasi BUMN melalui pembentukan holding company, pembentukan holding company BUMN pada sektor keuangan, dan pengaruh holding company BUMN pada sektor keuangan terhadap UMK-M.

\section{METODE}

\subsection{Jenis Penelitian}

Jenis penelitian ini adalah penelitian yuridis normatif dan praktis mengenai pengaruh holding company BUMN pada sektor keuangan terhadap pemberdayaan usaha mikro, kecil, dan menengah.

\subsection{Metode Pendekatan}

Metode pendekatan yang digunakan adalah pendekatan konseptual (conceptual approach), pendekatan filosofis (philosophy approach), dan pendekatan yuridis. Adapun pendekatan konseptual digunakan untuk mendesain perlindungan hukum bagi pihak ketiga melalui pembentukan suatu peraturan baru. Kemudian pendekatan filosofis dan yuridis digunakan untuk mengidentifikasi urgensi dan esensi pada rumusan masalah.

\subsection{Sumber Bahan Hukum}

Sumber data yang digunakan dalam penelitian ini adalah bahanbahan hukum yang terdiri dari bahan hukum primer, sekunder, dan tersier.

\subsection{Teknik Pengumpulan \\ Bahan Hukum}

Teknik pengumpulan data yang digunakan adalah metode penelitian studi pustaka (library research) yang terdiri dari buku-buku, jurnal ilmiah, media massa, dan sumber internet

\subsection{Teknik Analisis Bahan \\ Hukum}

Penelitian ini menggunakan teknik analisis data berupa analisis isi (content analysis). Analisis ini dilakukan dengan mengolah bahanbahan hukum yang telah dikumpulkan secara sistematis untuk menghasilkan kesimpulan yang dapat menjawab rumusan masalah.

\section{HASIL}

Berdasarkan hasil penelitian menggunakan metode-metode sebagaimana telah dijelaskan sebelumnya menghasilkan jawaban dari pada permasalahan dan penelitian hukum bahwasanya pada rencana pembentukan holding company BUMN pada sektor keuangan namun perusahaanperusahaan di dalamnya tidak memiliki kesamaan bidang kegiatan usaha merupakan pertama kalinya terjadi di Indonesia. Berdasarkan hasil penelitian tersebut maka perlu untuk dikaji secara komprehensif melalui perspektif hukum terhadap pengaruh rencana holding company BUMN. Disamping itu rencana tersebut pun diniatkan untuk mendorong pertumbahan dan perkembangan para pelaku UMKM di Indonesia.

\section{PEMBAHASAN}

\subsection{Aspek Hukum Holding Company BUMN}

Pelaksanaan holding company di Indonesia tidak diatur secara jelas dalam peraturan perundang-undangan apapun. Holding company ini merupakan best practice yang telah dilakukan di berbagai negara seperti Singapura dan Malaysia, yang mana dalam pelaksanaannya dapat mencatatkan kinerja yang stabil pada setiap tahunnya. Salah satu contohnya yaitu pada tahun 2018, holding company Termasek Singapura memperoleh laba sebesar 26,6 miliar SGD dari total pendapatan sebesar 107 miliar SGD. ${ }^{8}$ Walaupun pelaksanaan holding company dinilai tidak bertentangan dengan peraturan perundang-undangan, namun dalam pelaksanaannya harus tetap memperhatikan aspek-aspek hukum yang berkaitan. Terdapat beberapa aspek hukum yang harus diperhatikan dalam melaksanakan pembentukan holding company.

Pertama, terkait mekanisme holding company BUMN. BUMN merupakan badan usaha yang sebagian besar atau seluruhnya dimiliki oleh negara, dalam artian paling sedikit sebanyak $51 \%$ saham dalam BUMN dimiliki oleh negara. Dalam hal pembentukan holding company, salah satu 
dari dua atau lebih BUMN untuk menjadikan BUMN lainnya sebagai anak perusahaan perlu melakukan penyertaan saham sebagian besar atau seluruhnya terhadap BUMN lainnya. Sesuai dengan definisi anak perusahaan pada Pasal 1 butir 2 Peraturan Menteri Negara Badan Usaha Milik Negara Nomor PER03/MBU/2012 tentang Pedoman Pengangkatan Anggota Direksi dan Anggota Dewan Komisaris Anak Perusahaan Badan Usaha Milik Negara ("Permeneg BUMN 3/2012") mengartikan bahwa anak perusahaan BUMN adalah perseroan terbatas yang sebagian besar atau seluruh sahamnya dimiliki oleh BUMN atau perseroan terbatas yang dikendalikan BUMN. Mekanisme yang pada umumnya dilakukan di Indonesia dalam pembentukan holding company yaitu pengambilalihan atau akuisisi. Terkait pelaksanaan akuisisi BRI terhadap Pegadaian dan PT PNM harus tunduk pada Pasal 6 dan 7 Peraturan Pemerintah Nomor 43 Tahun 2005 tentang Penggabungan, Peleburan, Pengambilalihan, dan Perubahan Bentuk Badan Hukum Badan Usaha Milik Negara (“PP 43/2005”), yang pada intinya untuk melakukan akuisisi harus memenuhi hal-hal sebagai berikut: ${ }^{9}$

1. Mendapat persetujuan Rapat Umum Pemegang Saham ("RUPS");

2. memperhatikan kepentingan perusahaan yang bersangkutan, pemegang saham minoritas, dan karyawan perusahaan yang bersangkutan;

3. memperhatikan asas persaingan usaha yang sehat dan kepentingan masyarakat; dan

4. memperhatikan kepentingan kreditor yang ada.

Selain itu pada Pasal 8 PP 43/2005 mengisyaratkan bahwa pelaksanaan akuisisi juga harus memperhatikan ketentuan pada Undang-Undang Nomor 40 Tahun 2007 tentang Perseroan Terbatas ("UU PT"). Dengan demikian, jika pelaksanaan akuisisi telah dilaksanakan, holding company dari sisi kepemilikan saham telah terpenuhi secara hukum.

Kedua, dalam melaksanakan restrukturisasi BUMN melalui holding company perlu memperhatikan Pasal 73 UU BUMN, yang menjelaskan bahwa ruang lingkup dari pelaksanaan restrukturisasi BUMN meliputi:10

1. Restrukturisasi sektoral yang pelaksanaannya disesuaikan dengan kebijakan sektor dan/atau ketentuan perundang- undangan;

2. restrukturisasi perusahaan yang meliputi:

a. peningkatan intensitas persaingan usaha;

b. penataan hubungan fungsional pemerintah selaku regulator dan BUMN selaku badan usaha, termasuk di dalamnya penerapan prinsip-prinsip tata kelola yang baik dan menetapkan arah dalam rangka pelaksanaan

kewajiban pelayanan publik; dan

c. restrukturisasi internal yang mencakup keuangan, organisasi/manajemen, operasional, sistem, dan prosedur.

Ketiga, hak dan kewajiban perusahaan induk. Sepertinya yang telah dijelaskan sebelumnya bahwa terbentuknya holding company yaitu akibat adanya kepemilikan saham mayoritas pada anak perusahaannya. Kepemilikan saham tersebut menyebabkan perusahaan induk memiliki hak untuk menerima dividen sejumlah saham yang dimilikinya pada anak perusahaan, sesuai dengan ketentuan pada Pasal 71 ayat (2) UU PT. Jika mengacu pada ketentuan penerimaan dividen, adanya holding company dinilai akan benar-benar memperkuat pondasi keuangan perusahaan induk. Selain itu, posisi perusahaan induk sebagai pemegang saham mayoritas berdasarkan Pasal 88 UU PT, telah memberikan hak suara yang besar dan sangat berpengaruh. Dengan demikian, hak dan kewajiban perusahaan induk holding company dalam kepemilikan sahamnya pada anak perusahaan memberikan hakhak pemegang saham pada umumnya berdasarkan UU PT dan juga memberikan 
kekuatan pengendalian lewat hak suara dalam RUPS.

Seperti yang telah dijelaskan bahwa pelaksanaan holding company tidak diatur secara jelas dalam peraturan perundang-undangan, namun dalam pelaksanaannya terdapat beberapa aspek hukum yang berkaitan. Dapat dikatakan bahwa tindakan akuisisi dengan tujuan holding company merupakan suatu tindakan hukum yang memunculkan adanya suatu akibat hukum tersendiri. Terdapat beberapa akibat hukum yang muncul karena pelaksanaan pembentukan holding company.

Pertama, Status hukum anak perusahaan. Akibat yang timbul dari pelaksanaan pembentukan holding company melalui akuisisi oleh BUMN atau perusahaan induk terhadap BUMN lainnya atau anak perusahaan mengubah status BUMN yang diakuisisi yang tadinya berbentuk BUMN menjadi anak perusahaan BUMN, dalam artian secara yuridis berbentuk perseroan terbatas biasa. Perlu ditekankan kembali bahwa yang dimaksud BUMN adalah badan usaha yang seluruh atau sebagian besarnya dimiliki negara melalui penyertaan langsung. ${ }^{11}$ Sedangkan akuisisi yang dilakukan oleh perusahaan induk, berarti bahwa modal yang ada dalam anak perusahaannya merupakan penyertaan langsung dari BUMN, bukan penyertaan langsung dari negara. Selain itu, walaupun posisi BUMN setelah melakukan akuisisi menjadi perusahaan induk yang memiliki kendali terhadap anak perusahaannya atas mayoritas komposisi sahamnya, masing-masing perusahaan secara yuridis tetap merupakan suatu entitas yang terpisah antara satu dengan yang lainnya. Dalam artian kendali yang dipegang oleh perusahaan induk timbul karena posisinya sebagai pemegang saham. Sesuai dengan ketentuan Pasal 3 ayat (1) UU PT, yang menjelaskan bahwa pemegang saham Perseroan dan tidak bertanggung jawab secara pribadi atas perikatan yang dibuat atas nama
Perseroan dan tidak bertanggung jawab atas kerugian Perseroan melebihi saham yang dimiliki.

Kedua, Pertanggungjawaban perusahaan induk dalam holding company.

Dasar hukum pertanggungjawaban perusahaan induk dengan anak perusahaan dalam UU PT menjelaskan bahwa terdapat kemandirian antara induk dan anak perusahaan sebagai subyek hukum yang mandiri dan berhak untuk melakukan perbuatan hukum sendiri. Berdasarkan penjelasan tersebut perusahaan induk sebagai subyek hukum yang mandiri tidak bertanggung jawab atas perbuatan hukum yang dilakukan oleh anak perusahaan. Namun, dalam realitas bisnisnya kemandirian hukum dalam holding company justru menimbulkan risiko penyelewengan terhadap hukum yang berlaku karena terdapat pembatasan pertanggungjawaban. Maka dari itu, perlu adanya kejelasan hukum terhadap pertanggungjawaban perusahaan induk terhadap anak perusahaannya, yang salah satunya melalui prinsip Piercing the Corporate Veil. Prinsip Piercing the Corporate Veilmerupakan prinsip yang membenarkan penghapusan tanggung jawab terbatas pemegang saham dalam keadaan-keadaan tertentu. ${ }^{12}$ Sebenarnya secara ekplisit penjelasan prinsip tersebut sudah tertuang dalam Pasal 3 ayat (2) UU PT yang menyebutkan bahwa hapusnya pertanggungjawaban terbatas pemegang saham perseroan terjadi bila: ${ }^{13}$

a. persyaratan Perseroan sebagai badan hukum belum atau tidak terpenuhi;

b. pemegang saham yang bersangkutan baik langsung maupun tidak langsung dengan itikad buruk memanfaatkan Perseroan untuk kepentingan pribadi;

c. pemegang saham yang bersangkutan terlibat dalam perbuatan melawan hukum yang dilakukan oleh Perseroan; atau

d. pemegang saham yang bersangkutan baik langsung maupun tidak langsung secara melawan hukum menggunakan kekayaan Perseroan, yang mengakibatkan kekayaan Perseroan menjadi tidak cukup untuk melunasi utang Perseroan.

Selain itu, adapun landasan yuridis yang menjadi tanggung jawab perusahaan induk terhadap tindakan anak 
perusahaannya sebagaimana dikemukakan oleh Mohr dan Raajismakers, meliputi: ${ }^{14}$

a. Perusahaan induk bertanggung jawab terhadap tindakan anak perusahaannya dalam suatu perjanjian atau kontrak yang bersifat pelengkap. Dalam hal ketentuan hukum yang mengatur, yaitu pada Pasal 1644 Kitab Undang-Undang Hukum Perdata, bahwa suatu perbuatan telah dilakukan atas tanggungan persekutuan hanyalah mengikat sekutu yang melakukan perbuatan itu saja dan tidaklah mengikat sekutu-sekutu lainnya, kecuali sekutu lainnya telah memberikan manfaat bagi persekutuan. ${ }^{15}$ Dengan itu, meskipun perusahaan induk tidak memberikan pernyataan persetujuan, tetap dapat diminta pertanggungjawaban apabila telah memperoleh keuntungan yang dilakukan oleh anak perusahannya.

b. Permodalan Rendah (Undercapitalization), yang berarti apabila perusahaan induk lalai dalam melengkapi anak perusahaannya dengan alat modal dalam perimbangan yang wajar dengan luasnya operasional perusahaan.

c. Dalam hal atas dasar penyalahgunaan aturan, pertanggungjawaban

perusahaan induk dapat terjadi apabila perusahaan induk melanggar ketentuan hukum yang sebenarnya tidak diperkenankan.

\subsection{Pembentukan Holding Company BUMN pada Sektor Keuangan}

Di Indonesia, BUMN yang bergerak pada sektor keuangan kebanyakan terdiri dari lembaga keuangan perbankan dan lembaga keuangan non perbankan. Kedua lembaga tersebut, dalam menjalankan kegiatan usahanya memberikan kontribusi terhadap perekonomian nasional sekaligus memberikan fasilitas perihal finansial kepada seluruh masyarakat. Pembentukan holding company BUMN pada sektor keuangan sebenarnya telah direncanakan serta ditargetkan oleh pemerintah sejak tahun 2016..$^{16}$ Namun, hingga saat ini belum terdapat perkembangan yang nyata dan berarti terkait pembentukan holding company BUMN pada sektor keuangan.

$$
\text { Semangat pemerintah untuk }
$$

menargetkan holding company BUMN sektor keuangan sejak tahun 2016 menemukan jalan terang, tepatnya pada akhir tahun 2020 seperti yang telah disinggung pada awal penjelasan bahwa awal mula munculnya rencana holding company antara BRI, Pegadaian, dan PT PNM yang datang dari inisiatif Menteri BUMN RI, Erick Thohir, dengan sasaran utama dalam pengembangan dan dukungan terhadap UMK-M di Indonesia. Erick Thohir memaparkan bahwa tujuan dari holding company yaitu untuk mendorong pengusaha- pengusaha kecil berkembang, serta seluruh elemen pengusaha sampai ke elemen usaha mikro layak mendapatkan pinjaman dana. Adapun tujuan lainnya yaitu demi terciptanya sinergi jaringan ekspansi usaha serta dalam rangka sinergi digitalisasi dan platform. Pada dasarnya, tujuan dari restrukturisasi BUMN melalui pembentukan holding company untuk: a) meningkatkan kinerja dan nilai perusahaan; b) memberikan manfaat berupa dividen dan pajak kepada negara; c) menghasilkan produk dan layanan dengan harga yang kompetitif kepada konsumen; d) memudahkan pelaksanaan privatisasi. ${ }^{17}$

Pembentukan holding company BUMN bagi lembaga keuangan perbankan menjadi salah satu langkah strategis yang berintikan kebijakan untuk memperbaiki kondisi solvibilitas dan profibilitas perbankan, melangsungkan kehidupan perbankan dengan prospek baik, dan menoptimalkan lagi fungsi perbankan sebagai lembaga intermediasi. Di sisi lain, bagi lembaga keuangan non perbankan dalam kaitannya atas pembentukan holding company BUMN tidak berbeda jauh dengan manfaat yang didapatkan oleh lembaga keuangan perbankan. Dilihat dari tujuan lembaga keuangan non perbankan merupakan tujuan yang masih ada pada garis yang sama 
dengan lembaga keuangan perbankan, yang meliputi: 1) Menghimpun dana dengan mengeluarkan surat-surat berharga; 2) Memberikan kredit; 3) Menjadi perantara bagi para pelaku usaha; 4) dan fungsi lainnya sesuai peraturan perundang-undangan. Jika dilakukan analisis, sebenarnya antara lembaga keuangan perbankan dengan lembaga keuangan bukan bank memiliki persamaan dalam menjalankan fungsinya, khususnya dalam hal menghimpun dana dan pemberian dana terhadap masyarakat dengan mekanisme kredit. Hanya saja cakupan kegiatan lembaga keuangan perbankan lebih luas dan memiliki cakupan kegiatan usaha yang kompleks.

\subsection{Pengaruh Holding Company BUMN pada Sektor Keuangan Terhadap UMK-M}

Rencana holding company antara BRI, Pegadaian, dan PT PNM akan memiliki fokus tujuan terhadap pembiayaan dan pemberdayaan UMK-M sebagaimana disampaikan juga oleh Menteri BUMN, Erick Thohir. Namun, ternyata terdapat beberapa kalangan masyarakat yang masih ragu, bahkan menolak adanya rencana holding company tersebut, Faisal Basri mengatakan bahwa rencana pemerintah untuk membentuk holding company bertentangan dengan gagasan memajukan UMK-M secara totalitas, karena seolah-olah persoalan UMK-M hanya tentang keuangan atau modal. Padahal, UMK-M juga memerlukan akses pasar, inovasi, akses teknologi, dan lainnya. ${ }^{18}$ Sementara itu, Ketua Umum SP Pegadaian, Ketut Suhardiono berpendapat bahwa kebijakan holdingisasi tidak akan menguntungkan bagi Pegadaian, mengingat nasabah Pegadaian sebagian besar merupakan masyarakat kecil.

Melihat uraian di atas, munculnya pro dan kontra terkait tujuan holding company BUMN mengartikan bahwa nasib UMK-M di masa mendatang perlu diproyeksikan secara matang agar nantinya bisa membawa para pelaku usaha kepada keadaan yang lebih baik lagi. Seperti yang dijelaskan sebelumnya, bahwa keberadaan para pelaku UMK-M di Indonesia sangat penting dalam perekonomian nasional diantaranya sebagai pemeran utama dalam kegiatan ekonomi, penyedia lapangan kerja terbesar, pemain penting dalam pengembangan perekonomian lokal dan pemberdayaan masyarakat, pencipta pasar baru, serta kontribusi terhadap neraca pembayaran. Selama ini, perkembangan UMK-M di Indonesia cenderung lambat karena disebabkan baik faktor internal maupun eksternal lingkungan usaha seperti halnya berkaitan dengan modal usaha. Dalam mengembangan usaha, UMK-M tentu harus meningkatkan kapasitas kegiatan produksinya yang mana jelas memerlukan modal yang tidak sedikit. Tidak semua pelaku usaha yang ingin membangun pondasi usaha dari awal mempunyai pondasi modal yang kuat, dengan demikian perlu hadirnya lembaga keuangan yang dapat memberikan akses pembiayaan kepada para pelaku usaha.

Berdasarkan fakta, UMK-M di Indonesia masih minim dalam hal permodalan serta rendahnya kualitas Sumber Daya Manusia ("SDM"), menyebabkan UMK-M belum mampu mengimbangi perkembangan keinginan konsumen dan belum mampu bersaing secara global. Berdasarkan data Sensus Ekonomi 2016 ("SE2016"), UMK-M sebanyak $\pm 60 \%$ mengalami kendalan terkait permodalan. Selain itu, berdasarkan SE2016, mayoritas pelaku UMK-M mengeluarkan modal awal yang berasal dari keuangan pribadi ataupun berasal dari sumber penyedia pembiayaan informal, bahkan terhitung hanya $7 \%$ yang mengandalkan modal dari lembaga keuangan perbankan. ${ }^{19}$ Pada tahun 2020 berdasarkan data BPS, menunjukkan bahwa sekitar 69,02\% UMK-M mendapati permasalahan pada modal usaha. ${ }^{20}$ Adanya rencana holding company BUMN sektor keuangan tentunya menjadi suatu harapan tersendiri bagi para pelaku UMK-M untuk bisa membangun pondasi usahanya melalui modal usaha yang berkecukupan. Jika menganalisis terkait rencana 
holding company antara BRI, Pegadaian, dan PT PNM, pertamatama perlu diketahui bahwa BRI merupakan lembaga keuangan perbankan berbentuk perseroan terbatas yang tunduk langsung pada Undang-Undang Nomor 10 Tahun 1998 tentang Perbankan ("UU Perbankan"), merupakan badan usaha yang menghimpun dana dari masyarakat dalam bentuk simpanan dan menyalurkannya kepada masyarakat dalam bentuk kredit dan/atau bentuk-bentuk lainnya dalam rangka meningkatkan taraf hidup rakyat banyak, sesuai dengan ketentuan Pasal 1 angka 2 UU Perbankan. Sedangkan Pegadaian dan PT PNM bukan merupakan lembaga keuangan perbankan. Pegadaian merupakan BUMN (Persero) yang bergerak pada sektor keuangan berdasarkan Peraturan Pemerintah Nomor 51 Tahun 2011 ("PP Pegadaian"), yang memiliki cakupan kegiatan usaha pinjaman dana berdasarkan hukum gadai, jaminan fidusia, serta pelayanan jasa titipan, taksiran, sertifikasi, sesuai dengan ketentuan Pasal 2 ayat (2) PP Pegadaian. ${ }^{21}$ Sedangkan PT PNM merupakan BUMN (Persero) yang bergerak di bidang jasa keuangan, merupakan lembaga pembiayaan yang fokus terhadap akses permodalan, pendampingan, dan peningkatan kapabitas para pelaku UMK-M. Perbedaan antara BRI (Lembaga Keuangan Perbankan) dengan Pegadaian dan PT PNM (Lembaga Keuangan Non Perbankan) bukanlah suatu masalah yang dapat menghambat tujuan utama dari rencana holding company yaitu untuk mendukung para pelaku UMK-M di Indonesia, karena pada dasarnya ketiga perusahaan tersebut sama-sama memiliki target usaha untuk pemberian pinjaman dana terhadap para pelaku UMK-M.

Selanjutnya, menganalisis permasalahan permodalam UMK-M terhadap masing-masing lembaga baik lembaga keuangan perbankan maupun lembaga keuangan non perbankan. Menurut Darwin (2018), UMK-M memiliki aksesibilitas yang minim dan terbatas terhadap pembiayaan kredit dari lembaga keuangan perbankan. Hal tersebut disebabkan karena akses para pelaku usaha yang dinilai masih sulit untuk menembus sistem pembiayaan kredit perbankan. Selain itu, pelaku usaha juga minim terhadap informasi tentnag kredit pembiayaan usaha. ${ }^{22}$

Bentuk realisasi dari rencana holding company BUMN tersebut dapat menjadi solusi untuk berbagai permasalahan terkait permodalam bagi UMK-M di Indonesia. Dilaksanakannya rencana holding company ini sama sekali tidak mengubah masingmasing perusahaan secara yuridis, dalam artian BRI, Pegadaian, dan PT PNM masih merupakan suatu entitas hukum yang berdiri sendiri. Dari hal tersebut, muncul adanya kemandirian risiko karena masing-masing Pegadaian dan PT PNM sebagai anak perusahaan pada prinsipnya dalam setiap kewajiban, risiko, dan klaim pihak ketiga, tidak bisa dibebankan kepada perusahaan induk maupun perusahaan lainnya, sesuai dengan ketentuan Pasal 3 ayat (1) UU PT. Dengan demikian, tidak terdapat penyelarasan antara sistem ataupun kriteria anak perusahaan dengan induk perusahaan yang berarti Pegadaian dan PT PNM tetap pada fokus kegiatannya yaitu menjaring pelaku usaha pada lapisan bawah dalam pemberian kredit pembiayaan.

Justru dengan hadirnya BRI sebagai perusahaan induk, dapat memberikan suntikan modal yang lebih bagi Pegadaian dan PT PNM dalam pemberian kredit pembiayaan kepada para pelaku usaha. Hal tersebut juga dapat mendorong turunnya tingkat pengenaan bunga terhadap kredit yang diajukan para pelaku usaha, karena semakin kuatnya struktur modal usaha masing-masing anak perusahaan. Meningkatnya modal anak perusahaan menjadi suatu keuntungan tersendiri bagi perusahaan induk yaitu BRI dari sisi peningkatan profit dari dividen saham dalam anak perusahaan, dan pengerucutan jangkauan kredit pembiayaan terhadap para pelaku usaha.

Selain itu, dapat dilaksanakannya rencana holding company ini dapat menciptakan pengontrolan yang lebih mudah dan efektif. Pengontrolan yang 
dimaksud yaitu terkait hak pengawasan, efisiensi kegiatan operasional, kemudahan sumber modal, serta keakuratan pengambilan keputusan. Keberadaan perusahaan induk sebagai pemegang saham mayoritas pada anak perusahaan yang membuat beberapa ruang lingkup pengontrolan yang telah dijelaskan sebelumnya dapat dilaksanakan secara efektif. Pemegang saham mayoritas memiliki pengaruh yang sangat besar terhadap keputusan- keputusan dan langkah-langkah yang diambil demi nasib perusahaan kedepannya. Mengingat dalam ketentuan UU PT dikenal asas One Share One Vote atau satu saham satu suara, yang berarti bahwa setiap lembar saham yang dikeluarkan mempunyai satu hak suara, kecuali ditentukan lain oleh anggaran dasar, maka dari itu jika perusahaan induk memiliki saham lebih dari 50\% maka secara praktik telah memiliki mayoritas hak suara untuk menentukan arah keputusan yang diambil. Tidak dapat dipungkiri seperti yang telah dijelaskan sebelumnya terkait penurunan tingkat pengenaan bunga kredit pembiayaan juga tidak terlepas dari pengaruh kebijakan yang diambil oleh perusahaan, dengan itu maka BRI sebagai perusahan induk dapat mengatur segala strategi kebijakan secara serentak beserta anak perusahaannya dalam penghitungan tingkat bunga yang proporsional dengan kebutuhan dan kemampuan para pelaku usaha secara objektif.

\section{KESIMPULAN}

Berdasarkan uraian yang telah dipaparkan terkait analisis hukum terhadap restrukturisasi BUMN melalui mekanisme holding company, dapat ditarik beberapa poin kesimpulan meliputi:

1. Walaupun mekanisme holding company belum secara jelas diatur dalam peraturan perundang-undangan Indonesia, tetapi pelaksanaannya

dalam terdapat beberapa aspek hukum yang berkaitan. Aspek hukum tersebut meliputi aspek perusahaan dalam UU PT dan UU BUMN, Hak dan kewajiban perusahaan peserta holding company, serta penyertaan modal pada saat pelaksanaan holding company. Bahwa terdapat akibat hukum dari pelaksanaan pembentukan holding company, karena termasuk dalam suatu tindakan hukum. Akibat hukum tersebut timbul terhadap status hukum perusahaan, pertanggungjawaban perusahaan, komposisi pemegang saham perusahaan, serta peran perusahaan induk dalamholding company.

2. Pembentukan holding company BUMN bagi lembaga keuangan perbankan maupun non perbankan menjadi salah satu langkah strategis yang berintikan kebijakan untuk memperbaiki kondisi solvibilitas dan profibilitas, melangsungkan kehidupanusaha dengan prospek baik.

\section{SARAN}

Bahwa pada dasarnya rencana holding company BUMN antara BRI, Pegadaian, dan PT PNM jika dapat direalisasikan akan memberikan beberapa keuntungan tersendiri. jika dianalisis berdasarkan aspek kebutuhan UMK-M, fungsi masing-masing perusahaan, kekuatan modal perusahaan, keselarasan pengambilan keputusan dan kemudaham pengontrolan kegiatan usaha, dapat prediksi memberikan dampak yang postitif bagi lingkungan kegiatan usaha di sektor keuangan serta dalam rangka memberdayakan UMK-M di Indonesia.

\section{DAFTAR PUSTAKA}

1. https://news.ddtc.co.id/laba-bumnkerek-pendapatan-negara20352\#: :text=Peningkatan\%20kineria \%20penerimaan\%20yang\%20ditopang ,mencatat\%20penerimaan\%20sejumla h\%20Rp349\%20triliun. Diakses pada 7 Februari 2021, pukul 14.01

2. Munir Fuady, Hukum Perusahaan dalam Paradigma Hukum Bisnis, Bandung: Citra Aditya Bakti, 1999. 
3. Ryan Ardany, S., Akhmad Solikin, Pengaruh Restrukturisasi Melalui Pembentukan Holding BUMN Terhadap Kinerja Keuangan BUMN, Jurnal Hukum, Vol. 2 No. 2, 2018.

4. https://investor.id/multifinance/ke menbumn-holding-pembiayaanumkm-sasar-57-juta-nasabahumi. Diakses pada 7 Februari 2021, pukul 15:03

5. https://www.cnnindonesia.com/ek onomi/20210119065333-78595397/holding-bumn-ultramikro-diisi-bri-pnm-danpegadaian. Diakses pada 20 Januari 2021, pukul 7:00

6. Putra Adnan H., Peran UMK-M dalam Pembangunan dan Kesejahteraan Masyarakat Kabupaten Blora, Jurnal Analisa Sosiologi, 2016, hlm. 2.

7. Zulfikar R., Strategi Pengembangan UMK-M dengan Mengatasi Permasalahan UMKM dalam Mendapatkan Kredit Usaha, Makalah, hlm. 3.

8. Lisnawati, Tantangan Pembentukan Holding Badan Usaha Milik Negara di Indonesia, Jurnal, Vol. XI, No.01/Puslit/Januari/2019.

9. Peraturan Pemerintah Nomor 43 Tahun 2005 tentang

Penggabungan, Peleburan, Pengambilalihan, dan Perubahan Bentuk Badan Hukum Badan Usaha Milik Negara

10. Undang-Undang Nomor 19 Tahun 2003 tentang Badan Usaha Milik Negara

11. Pasal 1 butir 1 Undang-Undang Nomor 19 Tahun 2003 tentang Badan Usaha Milik Negara

12. Arif Fandy, Nyoman Satyayudha Dananjaya, Hapusnya Tanggung Jawab Terbatas Pemegang Saham Perseroan Terbatas Berdasarkan Prinsip Piercing The Corporate Evil, Hukum Bisnis Fakultas Hukum Universitas Udayana.

13. Undang-Undang Nomor 40 Tahun 2007 tentang Perseroan Terbatas
14. Muhammad Syafi'l, Piercing Corporateveil Terhadapholding company Dalam Tindakan Hukum Anak Perusahaan

15. Kitab Undang-Undang Hukum Perdata

16. Agus Prasetiyo, Restrukturisasi Badan Usaha Milik Negara Perbankan Melalui Pembentukan Holding Company di Indonesia, Junal Hukum No. 2 Vol. 4, Juli 2019, hlm.288.

17. Ibid., hlm. 290.

18. https://www.neraca.co.id/article/141361/ ekonom-faisal-basri-memintakementerian-bumn-batalkan-rencanaholding-umkm. Diakses pada 8 Februari, pukul 03:32

19. https://se2016.bps.go.id/umkum b/index.php/PendataanUmkUmb/index. Diakses pada 13 Februari, pukul 11:07.

20. s://lokadata.id/artikel/survei-bpsdayatahan-UMK-M-tinggal-3-bulan. Diakses pada 13 Februari, pukul 11:15.

21. Peraturan Pemerintah Nomor 51 Tahun 2011 tentang Perubahan Bentuk Badan Hukum Perusahaan Umum Pegadaian Menjadi Perusahaan Perseroan

22. Rita Diana, Analisis Aksesibilitas Permodalan Usaha Mikro Kecil pada Lembaga Keuangan Formal di Provinsi Sumatera Barat, Jurnal Ekonomi dan Pembangunan Vol. 27, No. 1, 2019, hlm. 68. 